\title{
Hematopoietic stem cell transplantation in acute myeloid leukemia from haploidentical donors compared with HLA-matched related donors
}

\begin{abstract}
Renat S. Badaev, Darina B. Zammoeva, Diana V. Babenetskaya, Natalia A. Il'ina, Anastasia I. Reshetova, Larisa L. Girshova, Irina G. Budaeva, Elena N. Tochenaya, Raisa I. Vabishchevich, Alexey V. Petrov, Yulia A. Alexeeva, Andrey Yu. Zaritskey, Dmitry V. Motorin
\end{abstract}

V.A. Almazov National Medical Research Center, St. Petersburg, Russia

Dr. Dmitry V. Motorin, V.A. Almazov National Medical

E-mail: dmotorin@mail.ru

Research Center, 2 Akkuratova St, St. Petersburg, Russia

Citation: Badaev RS, Zammoeva DB, Babenetskaya DV et al. Hematopoietic stem cell transplantation in acute myeloid leukemia from haploidentical donors compared with HLA-matched related donors. Cell Ther Transplant 2021; 10(2): 37-44.

\section{Summary}

Haploidentical SCT is an appropriate alternative for patients with acute myeloid leukemia (AML) in absence of compatible familial donor. Results of 57 haplo-SCT and 21 matched related donor SCT of patients with AML were assessed in the present study. Our aim was to compare clinical efficiency, complication rates and outcomes in the patients transplanted from related haploidentical donors versus HLA-compatible related donors. The rate of graft failure proved to be higher in haplo-SCT $(10.6 \%$ and $0 \%, \mathrm{p}=0.31$ ) and cumulative frequency of platelet recovery was much lesser in haplo-SCT group (65.2\% and $100 \%, p=0.00013$ ). However, the time before recovery of granulocytopoiesis and thrombocytopoiesis was similar. Frequencies of acute GVHD, RFS and OS were comparable. In MRD-HSCT group was tendency for higher rate of chronic GVHD (9.0\% and 22.9\%, $\mathrm{p}=0.07$ ) and relapse ( $40.7 \%$ and $16.6 \%, \mathrm{p}=0.15)$.
Active disease was the only factor with negative influence on results of SCT. Haplo-SCT was associated with higher rate of $\mathrm{D}+30(\mathrm{p}=0.001)$ and $100-\mathrm{d}(\mathrm{p}=0.011)$ mortality. In the group of patients after haplo-SCT without early mortality, GVHD grade 3-4 had negative influence on results of SCT. Hence, haploidentical HSCT is a plausible alternative for AML patients if HLA-compatible donor is not available. In particular, best results are obtained when haplo-HSCT is performed in the $1^{\text {st }}$ complete clinical remission.

\section{Keywords}

Acute myeloid leukemia, hematopoietic stem cell transplantation, related, haploidentical donor, HLA-compatible donor.

\section{Introduction}

Allogeneic hematopoietic stem cell transplantation (alloHSCT) is the only potentially curative treatment for the patients with acute myeloid leukemia (AML). Over last decades, the number of allo-HSCTs is substantially increased, including those performed in Russian Federation. Fully HLA-compatible sibling is the optimal marrow donor for allo-HSCT. However, a matched related donor (MRD) is available only for $30 \%$ of the patients $[1,2]$. HSCT from unrelated donor is associated with some problems, e.g., longer terms of donor activation and higher financial costs [3]. In this respect, allogeneic HSCT from haploidentical related donors with 50\% HLA compatibility seems to be a possible alternative. Implementation of posttransplant cyclophosphamide (PTCy) prophylaxis significantly decreased frequency of graft-versus-host disease (GVHD) and primary graft failure [4]. Over last years, clinical efficiency of haploidentical HSCT (haplo-HSCT) approached the results of allogeneic MRD-HSCTs [5, 6]. This permitted us 
to include haplo-HSCT into management standards of the patients with hematooncological diseases, e.g., at earlier stages of the disorder [7].

\section{Patients and methods}

The study included 68 patients with AML subjected to allogeneic HSCT at the V.A.Almazov Research Medical Center from 2011 to 2019. A total of 21 compatible related stem cell transplants and 57 haploidentical HSCTs were performed (Table 1). Both groups had comparable number of subjects with active disease at the time of transplantation (Haplo-HSCT, 32.7\%; MRD-HSCT, 31.6\%). Myeloablative conditioning was used more often in MRD-HSCT. In the patients with active disease and high numbers of blast cells at the moment of HSCT, the conditioning protocols with prior cytoreduction were used. The proportion of myeloablative, nonmyeloablative, and protocols with preceding $\mathrm{cy}$ toreduction was, respectively, $0 \%, 80.7 \%, 19.3 \%$; in haploHSCT versus $57.1 \%, 23.8 \%$, 19.1\% when transplanting from MRD. When performing haplo-HSCT, most patients received the following GVHD prophylaxis: posttransplant cyclophosphamide combined with calcineurin inhibitors and mycophenolate mofetil (94.7\%). In MRD-HSCT group a combination of calcineurin inhibitors with methotrexate was applied in most cases (76.2\%). Peripheral blood was more often used as a source of hematopoietic stem cells in both groups (89.5\% in haplo-HSCT; 76.2\% in MRD-HSCT). In the patients with high risk of posttransplant disease progression and absence of counterindications, prophylactic targeted therapy with low dosed Azacitidine was performed (53.8\% in haplo-HSCT, and $31.6 \%$ in MRD-HSCT). Also 4 patients after haplo-HSCT $(8.2 \%)$ received prophylactic donor lymphocyte infusion. By evaluating cytokine reactions, the patients with proven infections were excluded from the study. The patients were administered antibacterial drugs if it was not possible to make differential diagnostic between bacterial infections and cytokine reactions.

Primary endpoints of the study were relapse-free survival (RFS) and overall survival (OS). Death for any cause was

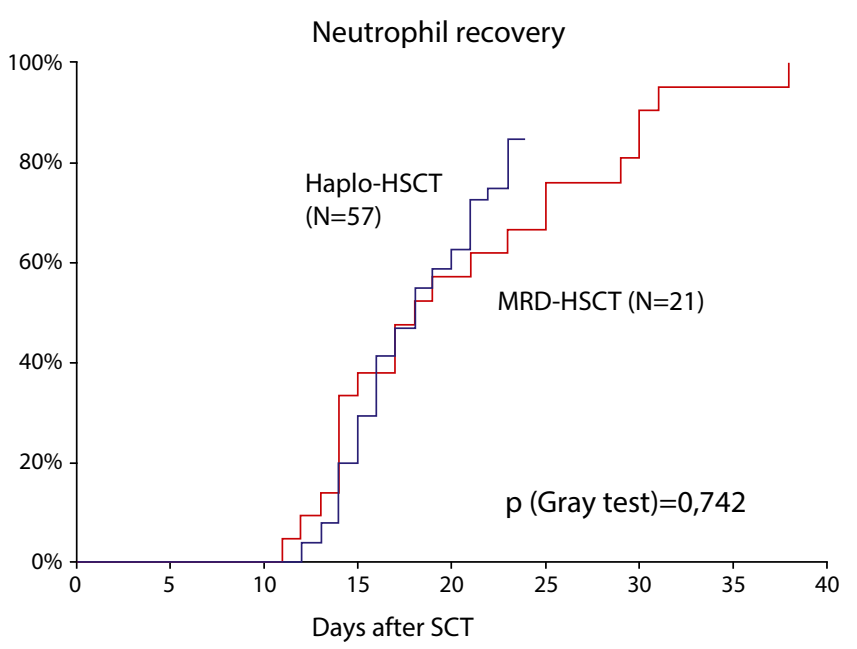

considered an event, and the surviving patients were censored by the date of last contact. Relapse was determined as bone marrow recurrence of disease or extramedullary lesions. The date of hematopoietic recovery was referred as the first of three subsequent days with absolute neutrophil number of $>0.5 \times 10^{9} / \mathrm{L}$, and thrombocyte recovery was referred as the first of seven subsequent days platelet numbers $>50 \times 10^{9} / \mathrm{L}$, without blood transfusion requirements.

Difference between the two groups upon evaluation of categorial factors was performed with coupling tables and Fisher criterion. Probability of relapse-free and overall survival (respectively, RFS and OS) was calculated with Kaplan-Meier analysis. Probability of granulo- and thrombocytopoiesis recovery, development of acute and chronic GVHD, relapses was calculated by the cumulative frequency method. Multifactorial analysis was performed using Cox regression. Influence of the following factors upon HSCT outcomes was tested: age and gender of patient and donor, disease status. Evaluation of chronic GVHD was carried out among the patients who survived for more than 90 days after HSCT.

\section{Results}

\section{Patient characteristics}

The patients subjected to haplo-HSCT were comparable by their age, gender, active disease rates at the time of HSCT and usage of posttransplant prophylaxis. Medians of age in haplo-HSCT and MRD-HSCT patients were, respectively, 40 years (18-61) and 32 years (18-61). Gender distribution was similar in both groups (ca. 50\%). A total of 10 repeated HSCTs were performed, due to AML relapse $(n=5)$ and graft rejection $(n=5)$.

Engraftment was achieved in $84.4 \%$ of cases (95\% CI 74.996.0) in haplo-HSCT versus $100 \%$ (95\% CI 100-100\%, $\mathrm{p}=0.742$ ) in MRD-HSCT (Fig. 1). Ten patients died within early terms after haplo-HSCT, before the engraftment was registered. Primary engraftment was more common in haplo-HSCT, however, being statistically insignificant ( $10.6 \%$ versus $0 \%, \mathrm{p}=0.31$ ). For the granulocyte recovery,

Figure 1. Hematopoiesis recovery in haploidentical and matched related HSCT

Abbreviations: Haplo-HSCT, Haploidentical stem cell transplantation; SCT, stem cells transplantation; MRD-HSCT, matched related donor hematopoietic stem cell transplantation. 
CLINICAL STUDIES

Table 1. Clinical features of the patients subjected to matched related HSCT (MRD-HSCT) and haploidendital familial transplant (haplo-HSCT)

\begin{tabular}{|c|c|c|}
\hline Clinical characteristics & MRD-HSCT, \% (N=21) & Haplo-HSCT, \% (N=57) \\
\hline Age of patient, years & 18-63 (med. 32) & 18-61 (med. 40) \\
\hline Sex of patients: $M / F$ & $12 / 9$ & $30 / 27$ \\
\hline $\begin{array}{l}\text { Disease status during SCT: } \\
\text { 1st } C R^{\text {st }} \\
2^{\text {nd }} C R \\
3^{\text {rd }} C R \\
\text { Active disease }\end{array}$ & $\begin{array}{l}52.6(10) \\
10.5(2) \\
5.3(1) \\
31.6(6)\end{array}$ & $\begin{array}{l}53.1(26) \\
10.2(5) \\
4.1(2) \\
32.7(16)\end{array}$ \\
\hline $\begin{array}{l}\text { Number of ChT courses before HSCT: } \\
1 \text { course } \\
2 \text { courses } \\
3 \text { courses } \\
>3 \text { courses }\end{array}$ & $\begin{array}{l}10.5(2) \\
42.1(8) \\
15.8(3) \\
31.6(6)\end{array}$ & $\begin{array}{l}12.2(6) \\
46.9(23) \\
16.3(8) \\
24.5(12)\end{array}$ \\
\hline Prophylactical therapy after HSCT & $31.6 \%(6 / 13)$ & $53.8 \%(21 / 18)$ \\
\hline Age of donor, years & 11-59 (med. 34) & 15-66 (med. 43) \\
\hline Sex of donors: M/F & $9 / 12$ & $30 / 27$ \\
\hline $\begin{array}{l}\text { Siblings } \\
\text { Parents } \\
\text { Children }\end{array}$ & $\begin{array}{l}100(21) \\
- \\
-\end{array}$ & $\begin{array}{l}33(19) \\
36.8(21) \\
29.8(17)\end{array}$ \\
\hline $\begin{array}{l}\text { CMV status (D/R): } \\
\text { Pos/pos } \\
\text { Pos/neg } \\
\text { Neg/pos } \\
\text { Neg/neg } \\
\text { Unknown }\end{array}$ & $\begin{array}{l}90.5(19) \\
- \\
4.8(1) \\
4.8(1) \\
-\end{array}$ & $\begin{array}{l}75.4(43) \\
5.3(3) \\
3.5(2) \\
- \\
15.8(9)\end{array}$ \\
\hline $\begin{array}{l}\text { AB0-incompatibility: } \\
\text { Matched } \\
\text { Major incompatibility } \\
\text { Minor incompatibility } \\
\text { Bidirectional incompatibility }\end{array}$ & $\begin{array}{l}57.1(12) \\
19.0(4) \\
19.0(4) \\
4.8(1)\end{array}$ & $\begin{array}{l}61.4(35) \\
24.6(14) \\
8.8(5) \\
5.3(3)\end{array}$ \\
\hline $\begin{array}{l}\text { Conditioning: } \\
\text { Myeloablative } \\
\text { Nonmyeloablative } \\
\text { With previous cytoreduction }\end{array}$ & $\begin{array}{l}57.1(12) \\
23.8(5) \\
19(4)\end{array}$ & $\begin{array}{l}- \\
80.7(46) \\
19.3(11)\end{array}$ \\
\hline $\begin{array}{l}\text { GVHD prophylaxis: } \\
\text { CsA + Mtx } \\
\text { CsA + MMF } \\
\text { PtCy + CsA (Tac) + MMF } \\
\text { a/ } \beta \text {-depletion }\end{array}$ & $\begin{array}{l}76.2(16) \\
9.5(2) \\
9.5(2) \\
4.8(1)\end{array}$ & $\begin{array}{l}- \\
- \\
94.7(54) \\
5.3(3)\end{array}$ \\
\hline $\begin{array}{l}\text { Stem cells source: } \\
\text { Peripheral blood } \\
\text { Bone marrow }\end{array}$ & $\begin{array}{l}76.2(16) \\
23.8 \text { (5) }\end{array}$ & $\begin{array}{l}89.5(51) \\
10.5 \text { (6) }\end{array}$ \\
\hline
\end{tabular}

Abbreviations: CsA, cyclosporin A; MMF, mycophenolate mofetil; Mtx, methotrexat; PtCy, posttransplant cyclophosphamide; Tac, tacrolimus; Haplo-HSCT, haploidentical stem cell transplantation; GVHD, Graft-versus-host disease; MRD-HSCT, matched related donor hematopoietic stem cell transplantation; HSCT, hematopoietic stem cell transplantation; ChT, chemotherapy; CMV, cytomegalovirus 
there was no significant timing difference, i.e., the medians of 17 days and 18 days in haplo-HSCT and MRD-HSCT settings, respectively. Cumulative frequency of thrombocyte recovery by the D+100 was sufficiently worse in haplo-HSCT 65.2\% (95\% CI 52.4-81.3) and 100\% (95\% CI 100-100\%, $\mathrm{p}=0.00013)$. Similarly, recovery of thrombocyte numbers was also longer in haplo-HSCT setting than in MRD-HSCT, with median values of, respectively, 30 days and 21 days $(\mathrm{p}=0.015)$. When performing haplo-HSCT, a cytokine reaction to hematopoietic stem cell infusion was observed in $85.7 \%$ of the cases $(n=42)$, however, without detectable severe responses.

\section{GVHD and relapse rates}

A trend for higher frequency of acute GVHD (grade 2-4) at 6 months was observed in haplo-HSCT group, i.e., $45.3 \%$ (95\% CI 31.7-64.6) and 36.3\% (95\% CI 20.0-65.6\%, p=0.173), as seen from Fig. 2. There were no differences observed for severe acute GVHD (grade 3-4) between the two mentioned groups: $16.1 \%(95 \%$ CI 7.6-34.4) in haplo-HSCT versus $25.6 \%$ (95\% CI $12.0-54.7 \%$ ) in MRD-HSCT ( $\mathrm{p}=0.5$ ). A tendency for higher rate of different stages of chronic GVHD (at 1 year) was observed in MRD-HSCT: $22.9 \%$ (95\% CI 11.362.6) as compared with $9.0 \%$ in haplo-HSCT (95\% CI 3.664.6, $\mathrm{p}=0.07$ ) (Fig. 3).

The median observation period was 294 days for the entire group (95\% CI 210-51), and 1299 days for the surviving patients (95\% CI 916-1798). A trend for increased relapse rate was found in the MRD-HSCT subgroup (40.7\%; 95\% CI 22.8-72.5) as compared to haplo-HSCT (16.6\%; 95\% CI $7.3-37.7 \%, p=0.151)$ as seen from Fig. 4. The median terms for relapses did not differ significantly: 256 days for MRDHSCT, and 114 days for haplo-HSCT setting ( $\mathrm{p}=0.104)$.
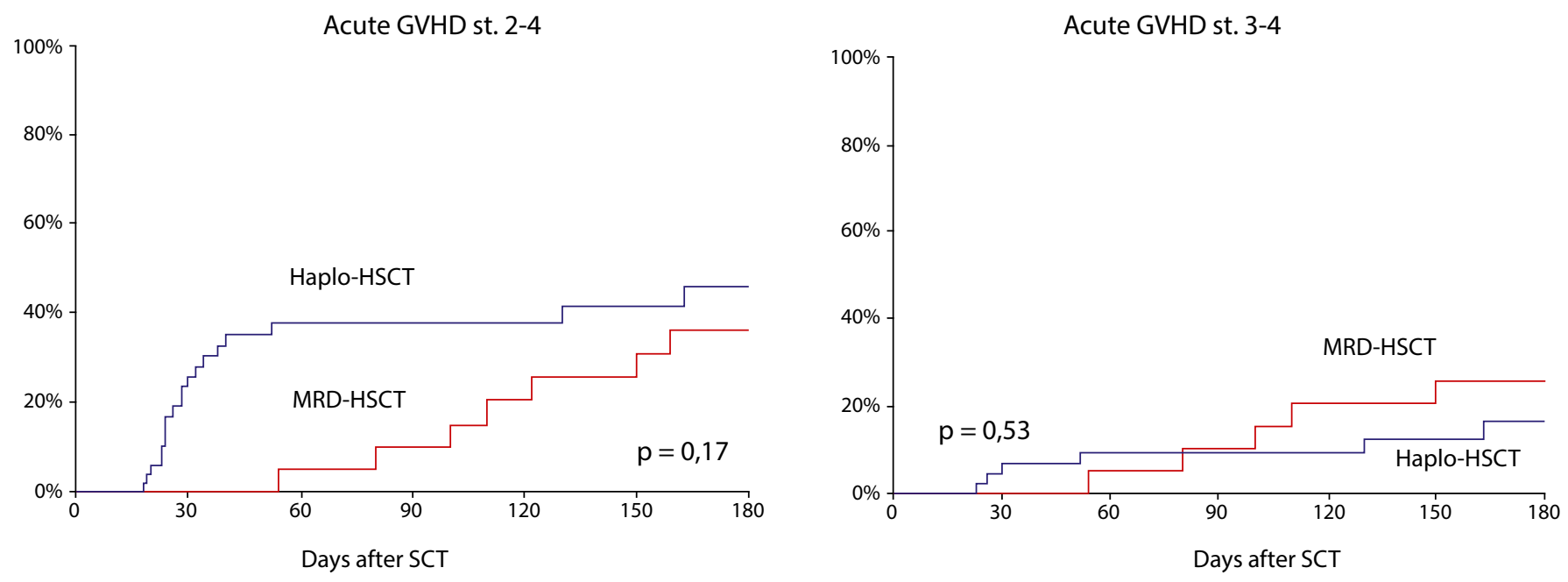

Figure 2. Cumulative frequency at day +180 of acute GVHD (a, stage 2-4; b, stage 3-4) in haplo-HSCT and MRD-HSCT

Abbreviations: GVHD, Graft-versus-host disease; Haplo-HSCT, Haploidentical stem cell transplantation; SCT, stem cells transplantation; MRD-HSCT, matched related donor hematopoietic stem cell transplantation; SCT, stem cells transplantation.

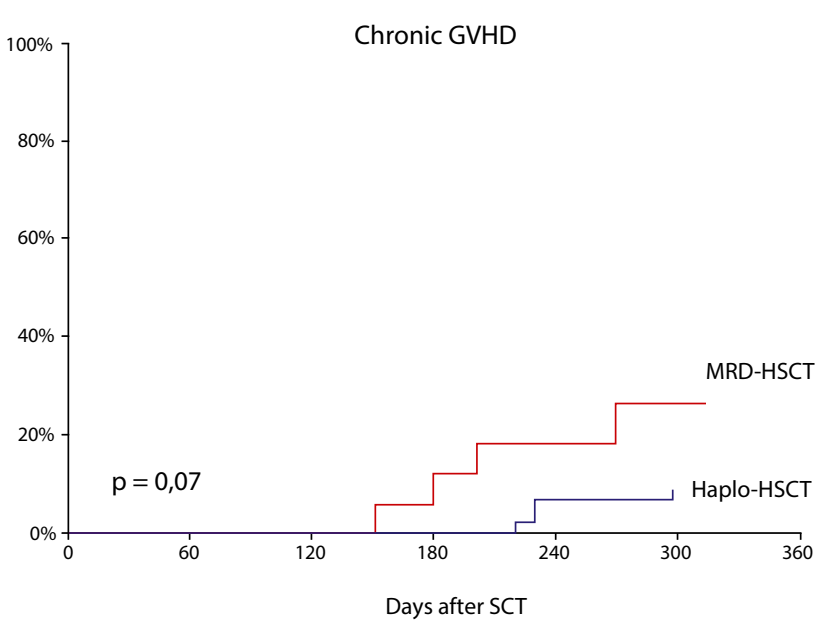

Figure 3. Cumulative frequency at 1 year of chronic GVHD in haplo-HSCT and MRD-HSCT

Abbreviations: GVHD, graft-versus-host disease; HaploHSCT, Haploidentical stem cell transplantation; SCT, stem cells transplantation; MRD-HSCT, matched related donor hematopoietic stem cell transplantation; SCT, stem cells transplantation.

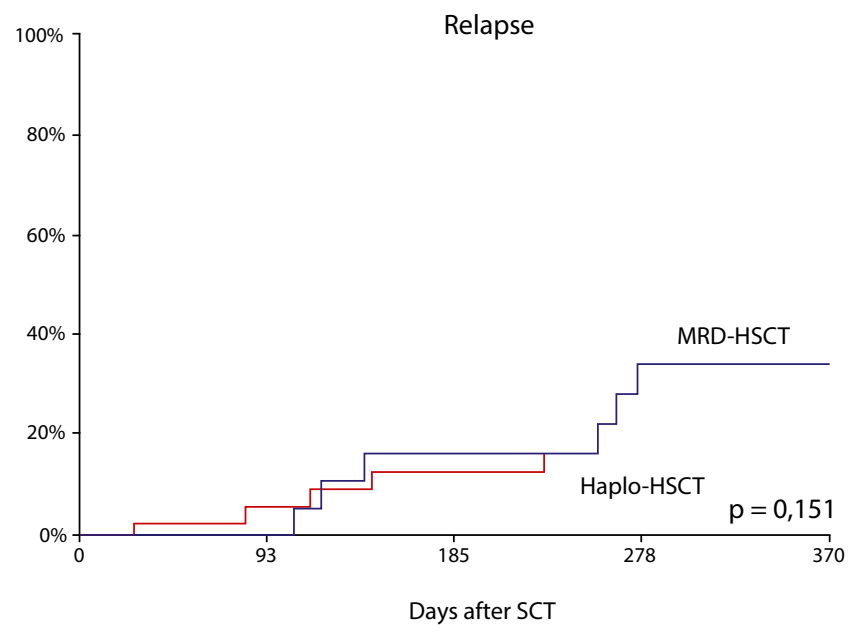

Figure 4. Cumulative frequency of AML relapse in haploidentical and MRD-HSCT

Abbreviations: Haplo-HSCT, Haploidentical stem cell transplantation; SCT, stem cells transplantation; MRD-HSCT, matched related donor hematopoietic stem cell transplantation; SCT, stem cells transplantation. 
Moreover, the results of 1-year relapse-free survival did not differ between the both groups, i.e., $40.8 \%$ for haplo-HSCT versus $52.4 \%$ for MRD-HSCT $(\mathrm{p}=0.44)$.

\section{Survival}

An increase in 30- and 100-day mortality was revealed in haplo-HSCT against MRD-HSCT: $21.1 \%$ vs $0 \%(\mathrm{p}=0.001)$; $41.5 \%$ vs $9.5 \%$ ( $\mathrm{p}=0.011)$, respectively. However, the one-year OS rates did not show a significant difference (haplo-HSCT, 42.9\% vs MRD-HSCT, 61.9\%; $\mathrm{p}=0.19$ ). Similarly, the data on relapse-free and overall survival did not differ for these groups (respectively, $\mathrm{p}=0.401$ and $\mathrm{p}=0.206$, Fig. 5).

The OS values were not influenced by the acute GVHD $(\mathrm{p}=0.292)$; severe acute GVHD stage $3-4(\mathrm{p}=0.168)$ and by evolving chronic GVHD ( $\mathrm{p}=0.174)$.

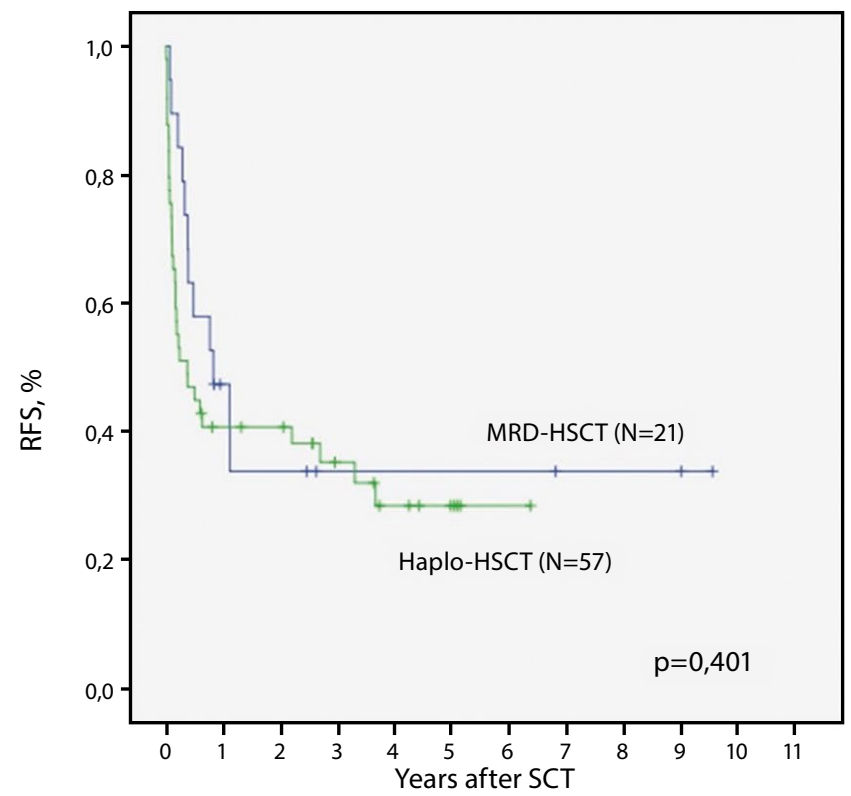

Meanwhile, the best results were obtained when performing HSCT in first remission. E.g., RFS value was $47.2 \%$ when transplanted in $1^{\text {st }}$ remission; $33.3 \%$ with HSCT in $2^{\text {nd }}$ or next remission, and $17.4 \%$ after HSCT in active phase of disease. The OS rates were as follows: $48.6 \%$ after HSCT in $1^{\text {st }}$ remission; $36.4 \%$ following HSCT in $>2^{\text {nd }}$ remission, and $18.2 \%$ after HSCT in active state of disease. Of note, these differences were not statistically significant, both for RFS and OS after HSCT at $1^{\text {st }}$ and next remissions ( $p>0.05$, Fig. 6).

\section{Survival analysis following haplo-HSCT}

We have made a separate data analysis in the group of haplo-HSCT patients, with similar results. Like in the total group of AML patients, overall survival rates were not affected by acute GVHD stage $2-4(\mathrm{p}=0.095)$, acute GVHD stage 3-4 $(\mathrm{p}=0.297)$ and chronic GVHD $(\mathrm{p}=0.255)$.

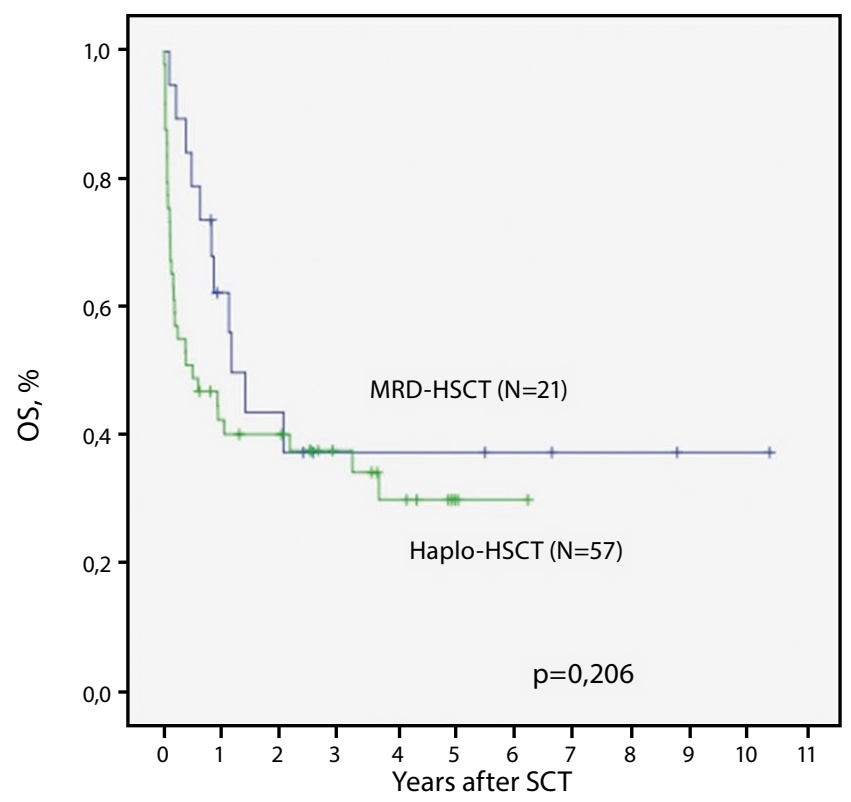

Figure 5. Comparison of RFS and 0S between SCTs from matched related and haploidentical donor

Abbreviations: RFS, relapse-free survival; OS, overall survival; Haplo-HSCT, Haploidentical stem cell transplantation; SCT, stem cells transplantation; MRD-HSCT, matched related donor hematopoietic stem cell transplantation; SCT, stem cells transplantation.
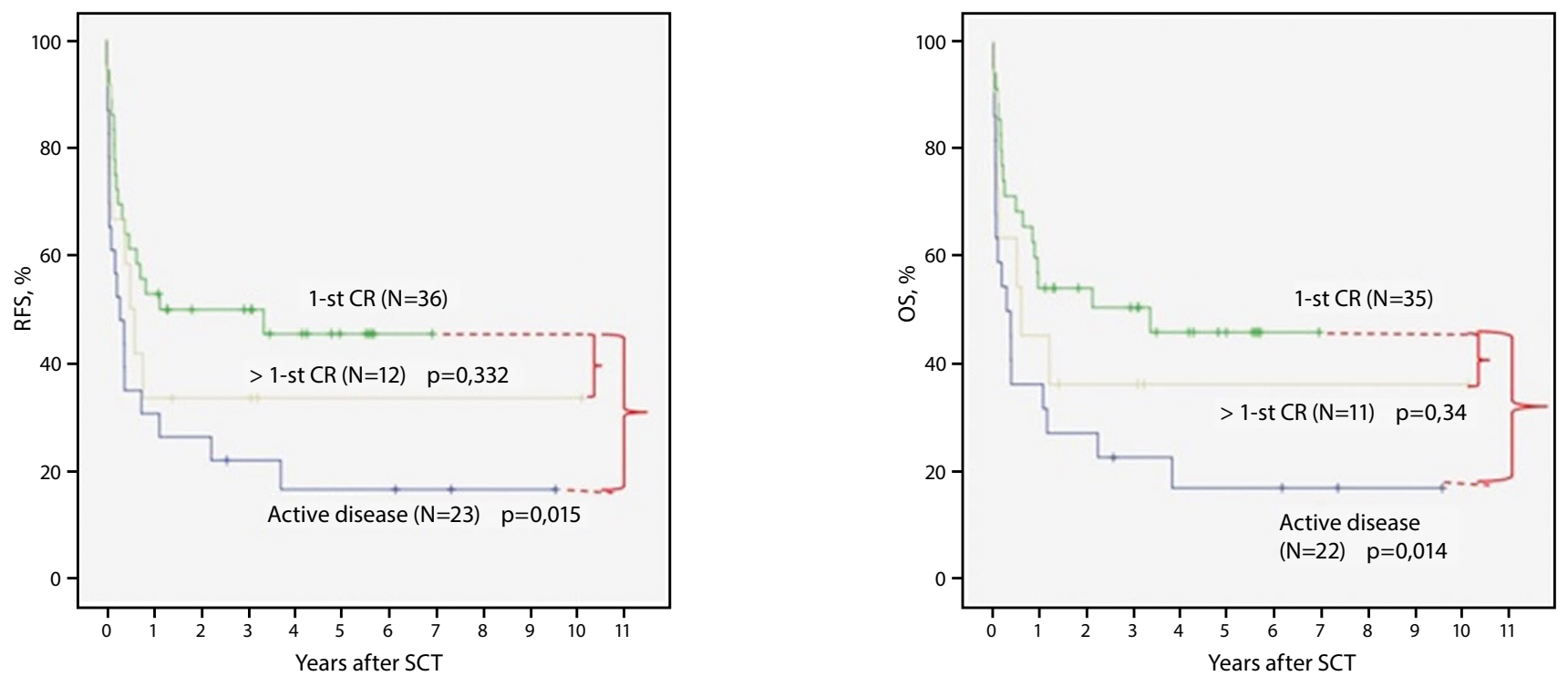

Figure 6. Effect of the disease status upon survival after allogeneic HSCT in total group of AML patients Abbreviations: RFS, relapse-free survival; OS, overall survival; CR, complete remission; SCT, stem cells transplantation. 
Presence of remission at the time of HSCT was again the sole factor, which led to significant worsening of RFS, i.e., $47.1 \%$ if treated in remission $v s 6.3 \%$ after HSCT in active disease $(p=0.001)$. The same differences were registered for OS rates, e.g., $48.5 \%$ for HSCT in remission $v s 6.3 \%$ for the patients transplanted in active disease $(\mathrm{p}=0.001)$ (Fig. 7). In multifactorial analysis active disease also was the only factor, influencing on OS ( $\mathrm{p}=0.008)$,

To assign causes of death after haplo-HSCT, appropriate sub-analysis was performed for this group. We have revealed, that among the patients, treated at the active stage of disease, compared to patients in $\mathrm{CR}$ at the moment of transplantation, a sufficient increase of 30-d mortality was observed, i.e., $47.6 \%$ vs $10.0 \%$ ( $\mathrm{p}=0.002)$. The most frequent causes of death in early period after haplo-HSCT were: infection $(75 \%, \mathrm{~N}=9)$, stroke $(16.7 \%, \mathrm{~N}=2)$ and progression $(8.3 \%, \mathrm{~N}=1)$.

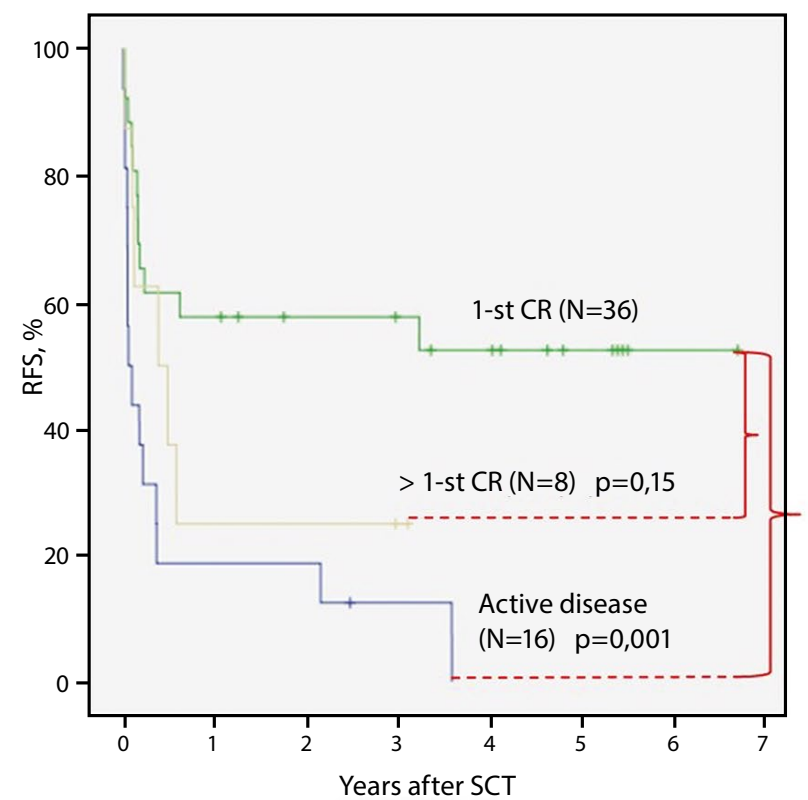

\section{Survival analysis in long-living haplo-HSCT patients}

Due to sufficient early-mortality among haplo-HSCT patients, we performed a sub-analysis for the patients who survived $>28$ days after SCT. A trend for improvement of RFS results was retained ( $\mathrm{p}=0.065)$, as well as OS data $(\mathrm{p}=0.067)$ when haplo-HSCT was carried out in remission of the disease, however, without statistical significance. The only factor which sufficiently influenced the results of haplo-HSCT in this group of patients was development of acute GVHD stage 3-4, causing a decrease of relapse-free survival, i.e. $0 \%$ in case of severe GVHD vs $53.1 \%$ in its absence $(\mathrm{p}=0.014)$, with similar effects on OS rates (severe GVHD $0 \%$ versus $54.8 \%$ in its absence $(p=0.012)$ ), as shown in Fig. 8.

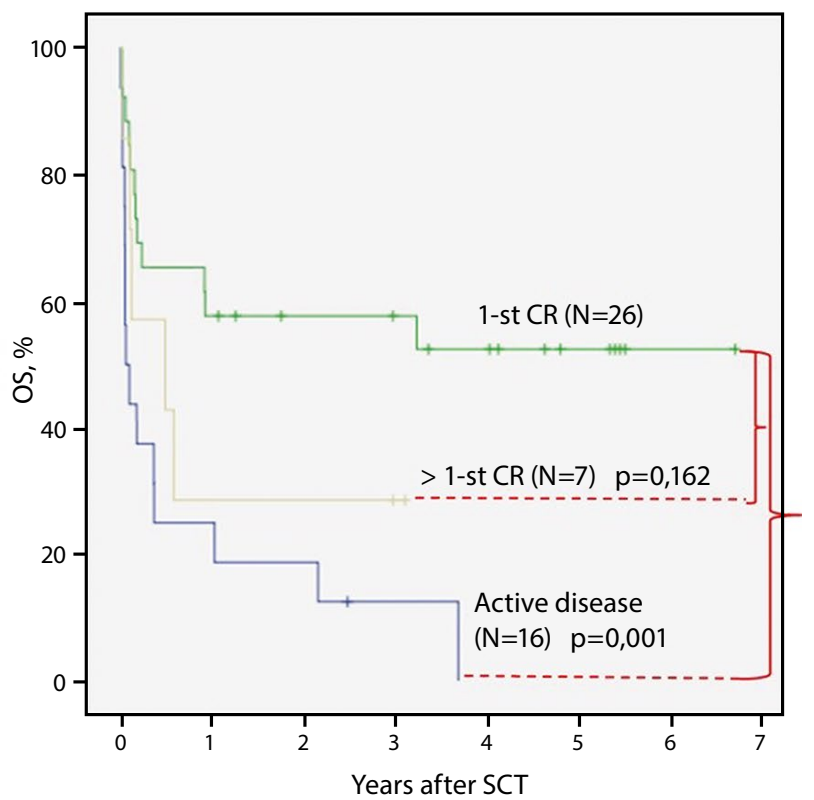

Figure 7. Effect of the disease status upon the AML patient survival after haploidentical HSCT

Abbreviations: RFS, relapse-free survival; OS, overall survival; $C R$, complete remission; SCT, stem cells transplantation.

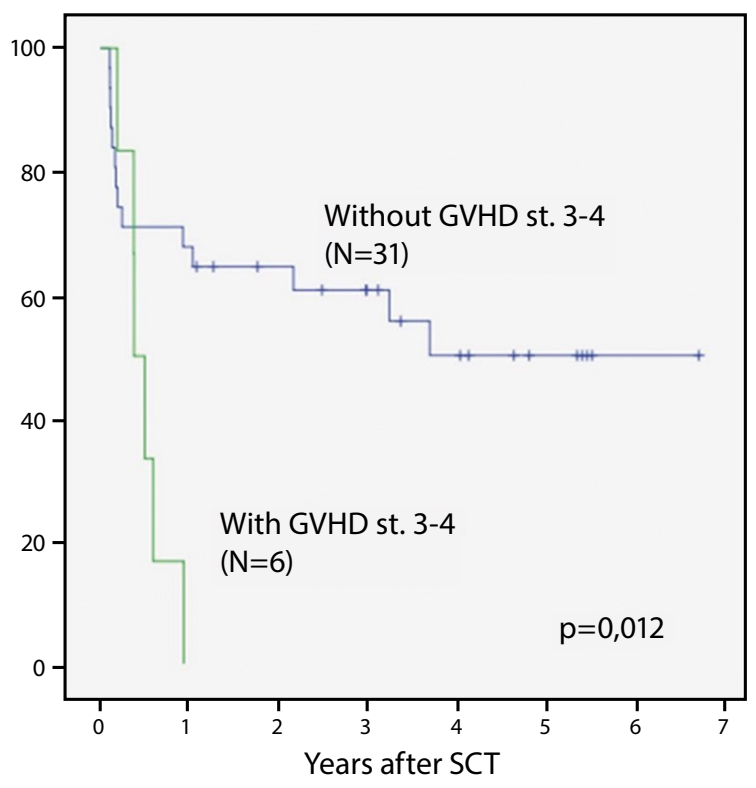

Figure 8. Effect of acute GVHD stage 3-4 on the overall survival of AML patients surviving $>28 \mathrm{~d}$ after haploidentical HSCT

Abbreviations: AML, acute myeloid leukemia; GVHD, graftversus-host disease; SCT, stem cells transplantation. 


\section{Discussion}

Proper choice for HLA-compatible donor is a prior task when performing allogeneic HSCT. Meanwhile, the aim of present study was to assess the results of haploidentical HSCT in AML patients and to compare them with outcomes of familial HLA-compatible HSCT. Due to low probability of finding HLA-compatible donors among siblings and in donor registries, the number of haploidentical HSCTs in our BMT Center was sufficiently increased and takes leading position at the present time.

When comparing time course of engraftment, we have observed high rates of primary graft failure, along with worse recovery of thrombocytopoiesis. This, however, provided an opportunity for repeated haplo-HSCT. Decreased rate of platelet reconstitution after HSCT may be connected with more pronounced immunological differences between patient and donor in haploidentical HSCT, as well as higher frequency of viral infections, e.g. cytomegalovirus. The results of survival analysis were comparable in the both groups. Therefore, our clinics now perform haplo-HSCT at broader basis, including the cases of relapse after MRD-HSCT.

According to our data, haplo-HSCT is associated with tendency for higher frequency of acute GVHD stage 2-4, thus being in agreement with other studies $[8,9]$. Meanwhile, frequency of severe acute GVHD (stage 3-4) in these patients did not differ from MRD-HSCT. However, frequency of chronic GHVD tended to be higher in MRD-HSCT. It may be connected with usage of posttransplant cyclophosphamide HSCT group, and, therefore, more pronounced immune suppression achieved with this schedule.

Of interest, AML relapses were more common in the patients subjected to MRD-HSCT, despite myeloablative conditioning applied in most patients of this group. It could be attributed to potent antileukemic action of allo-HSCT (graft-versus-leukemia effect) which seems to be more pronounced with haploidentical transplant [10]. Moreover, one may note, that majority of the patients who underwent haplo-HSCT received prophylactic targeted chemotherapy with low-dose Azacitidine, if no contraindications existed. Meanwhile, less than $1 / 3$ of the patients after MRD-HSCT received prophylactic therapy with Azacitidine +/- DLI only in cases of molecular relapse or evidence of active disease at the time of HSCT. Two patients in haploidentical and 2 patients in MRD groups received prophylactic donor lymphocyte infusions.

When evaluating overall survival, we did not see any difference between haploidentical and MRD-HSCT. Nonetheless, we saw certain features during posttransplant period in the both groups. We have revealed higher level of early mortality in the patients following haplo-HSCT on D+30 and D+100, with active malignant disease at HSCT, being among the main causes, increasing rate of early death post-transplant. Higher graft failure rates could also contribute to this early mortality. However, precise evaluation of engraftment was not feasible in these patients. Increased frequency of acute GVHD (grade 2-4) was also noted here.

Moreover, there are some data on longer reconstitution of immunity in haplo-HSCT [11]. Some workers suggest that it may lead to higher incidence of infectious complications, in particular, cytomegalovirus (CMV) reactivation [12]. Since all the patients with haplo-HSCT received non-myeloablative conditioning regimens, it seems that early mortality not to be associated with chemotherapeutic toxicity.

Active disease was associated with significantly poorer outcome after haplo-HSCT, being confirmed by the multifactorial analysis. The median survival in this group was only 25 days. The best results were obtained upon haploidentical HSCT performed in the 1st complete remission.

We have observed a sufficient proportion of the patients who deceased due to early (transplant-related) mortality within 1 month after transplantation. Meanwhile, the causes of death at later stages after transplantation significantly differ. A sub-analysis performed for the patients, who survived for $>28$ days post-HSCT, had shown, that OS in this long-living group was mainly influenced by acute GVHD (stage 3-4) whereas activity of primary disease prior to HSCT showed much lesser effect upon their survival.

\section{Conclusion}

1. Haploidentical HSCT is a plausible alternative for AML patients if HLA-compatible donor is not available.

2. Best results are obtained when haplo-HSCT is performed in the 1st complete remission.

3. Antileukemic effect of haplo-HSCT may be enhanced during posttransplant period by application of maintenance therapy with Azacitidine and donor lymphocyte infusions.

\section{Conflict of interest}

The authors report no conflicts of interest.

\section{Acknowledgement}

This study was financially supported by the Ministry of Science and Higher Education of the Russian Federation (Contract No. 075-15-2020-901).

\section{References}

1. Singh AK, McGuirk JP. Allogeneic Stem Cell Transplantation: A Historical and Scientific Overview. Cancer Res. 2016; 76(22):6445-6451. doi: 10.1158/0008-5472.CAN-16-1311

2. Tiercy JM. How to select the best available related or unrelated donor of hematopoietic stem cells? Haematologica. 2016; 101(6):680-687. doi: 10.3324/haematol.2015.141119

3. Afanasyev BV, Zubarovskaya LS, Borovkova AS, Kuzmich EV, Bykova TA, Deev RV,Isaev AA. Donor selection in allogeneic hematopoietic stem cell transplantation. Russian Journal of Pediatric Hematology and Oncology. 2016; 3(3):30-36 (In Russian). doi: 10.17650/2311-1267-2016-3-3-30-36

4. Luznik L, O'Donnell PV, Symons HJ, Chen AR, Leffell MS, Zahurak M, Gooley TA, Piantadosi S, Kaup M, Ambinder RF, et al. HLA-haploidentical bone marrow transplantation for hematologic malignancies using nonmyeloablative conditioning and high-dose, posttransplantation cyclophosphamide. Biol Blood Marrow Transplant. 2008; 14(6):641-650. doi: 10.1016/j.bbmt.2008.03.005 
5. Ciurea SO, Zhang MJ, Bacigalupo AA, Bashey A, Appelbaum FR, Aljitawi OS, Armand P, Antin JH, Chen J, Devine SM, Fowler DH, Luznik L, et al. Haploidentical transplant with posttransplant cyclophosphamide vs matched unrelated donor transplant for acute myeloid leukemia. Blood. 2015;126(8):1033-1040. doi: 10.1182/blood-2015-04-639831

6. Gu Z, Wang L, Yuan L, Huang W, Li M, Guan L, Wang Q, Gao Z, Zhao S, Luo L, et al. Similar outcomes after haploidentical transplantation with post-transplant cyclophosphamide versus HLA-matched transplantation: a meta-analysis of case-control studies. Oncotarget. 2017; 8(38):63574-63586. doi: $10.18632 /$ oncotarget. 18862

7. Passweg JR, Baldomero H, Bader P, Bonini C, Duarte RF, Dufour C, Gennery A, Kröger N, Kuball J, Lanza F, et al. Use of haploidentical stem cell transplantation continues to increase: the 2015 European Society for Blood and Marrow Transplant activity survey report. Bone Marrow Transplant. 2017; 52(6):811-817. doi: 10.1038/bmt.2017.34

8. Wang Y, Liu QF, Xu LP, Liu KY, Zhang XH, Ma X, Fan $\mathrm{ZP}$, Wu DP, Huang XJ. Haploidentical vs identical-sibling transplant for AML in remission: a multicenter, prospective study. Blood. 2015; 125(25):396-62. doi: $10.1182 /$ blood-2015-02-627786

9. Kunacheewa C. et al. Comparative efficacy and clinical outcomes of haploidentical stem cell transplantation to other stem sources for treatment in acute myeloid leukemia and myelodysplastic syndrome patients: a systematic review and meta-analysis. Cell transplantation. 2020; 29 : 0963689720904965.

10. Chang YJ. et al. Haplo-SCT mediates stronger GVL effect than HLA-matched sibling allograft by significantly reducing leukemia burden. Blood. 2018. 132: 2186. doi: 10.1182/ blood-2018-99-118409

11. McCurdy SR, Luznik L. Immune reconstitution after T-cell replete HLA-haploidentical transplantation. Semin Hematol. 2019;56(3):221-226. doi: 10.1053/j.seminhematol. 2019.03.005

12. Lin CH, Su YJ, Hsu CY, Wang PN, Teng CJ. Haploidentical allogeneic hematopoietic stem cell transplantation increases the risk of cytomegalovirus infection in adult patients with acute leukemia. Transpl Infect Dis. 2019; 21(4):e13096. doi: $10.1111 /$ tid.13096

\title{
Трансплантация гемопоэтических стволовых клеток при остром миелоидном лейкозе от гаплоидентичных доноров и HLA-совместимых родственных доноров
}

\author{
Ренат Ш. Бадаев, Дарина Б. Заммоева, Диана В. Бабенецкая, Наталья А. Ильина, Анастасия И. Решетова, \\ Лариса Л. Гиршова, Ирина Г. Будаева, Елена Н. Точеная, Раиса И. Вабищевич, Алексей В. Петров, \\ Юлия А. Алексеева, Андрей Ю. Зарицкий, Дмитрий В. Моторин \\ ФГБУ «Национальный медицинский исследовательский центр им. В. А. Алмазова, Санкт-Петербург, Россия
}

\section{Резюме}

Выбор гаплоидентичного донора является подходящей альтернативой в случае отсутствия HLA-сOвместимого сиблинга у пациентов с острым миелоидным лейкозом (ОМЛ). В настоящем исследовании проведена оценка результатов 57 гаплоидентичных (гапло-ТКМ) и 21 совместимой родственной ТКМ (СР-ТКМ) у пациентов с острым миелоидным лейкозом. Целью нашей работы было сравнение клинической эффективности, частоты осложнений и исходов терапии у больных, трансплантированных от гаплоидентичных и HLA-совместимых родственных доноров. Частота первичного неприживления трансплантата была незначительно чаще при гаплоТКМ $(10,6 \%$ и $0 \%, \mathrm{p}=0,31)$ и кумулятивная частота восстановления тромбоцитопоэза значимо ниже при гапло-ТКМ $(65,2 \%$ и $100 \%, \mathrm{p}=0,00013)$. При этом сроки восстановления гранулоцитопоэза и тромбоцитопоэза значимо не отличались. Частота острой РТПХ значимо не отличалась. При СР-ТКМ имелась тенденция к увеличению частоты хронической РТПХ $(9,0 \%$ и $22,9 \%, \mathrm{p}=0,07)$ и рецидива ОМЛ $(40,7 \%$ и 16,6\%, p=0,151). Результаты безрецидивной и общей выживаемости были сопоставимы при обоих видах ТКМ. Значимо ухудшало результаты проведение ТКМ на фоне прогрессии заболевания. При гапло-ТКМ была значимо выше частота 30-дневной $(\mathrm{p}=0,001)$ и 100-дневной $(\mathrm{p}=0,011)$. В группе пациентов после гапло-ТКМ без ранней летальности, развитие острой РТПХ 3-4 ст. значимо ухудшало результаты. Таким образом, гаплоидентичная ТГСК является пригодной альтернативой для пациентов с ОМЛ при отсутствии HLA-совместимого родственного донора. В частности, лучшие результаты достигаются при гапло-ТГСК, выполненной в первой полной клинической ремиссии.

\section{Ключевые слова}

Острый миелоидный лейкоз, трансплантация гемопоэтических стволовых клеток, родственная, гаплоидентичный донор, HLA-совместимый донор. 